\title{
ASSESSMENT AND ANTIMICROBIAL MODULATING ACTIVITY OF THE EXTRACT OF Baccharis cinerea DC. FROM CARIRI CEARENSE
}

\author{
AVALIAÇÃO DA ATIVIDADE ANTIMICROBIANA E MODULADORA DO \\ EXTRATO DE Baccharis cinerea DC. ORIUNDA DO CARIRI CEARENSE
}

\author{
Cleberton Torres SANTOS ${ }^{1}$; Luiz Eduardo Oliveira TEOTÔNIO' ${ }^{1}$; \\ Ana Paula Leite NASCIMENTO' ${ }^{1}$; Darcio Luiz de SOUSA JÚNIOR ${ }^{2}$; \\ Ítalo Mykaell da Silva BENJAMIN ${ }^{1}$; Cícera Natalia Figueiredo LEITE GONDIM²; \\ Henrique Douglas Melo COUTINHO ${ }^{2}$; Nadghia Figueiredo LEITE $^{1^{*}}$ \\ 1. Faculdade de Medicina Estácio do Juazeiro do Norte (ESTÁCIO|FMJ), Juazeiro do Norte, CE, Brasil; 2. Departamento de Química \\ Biológica, Universidade Regional do Cariri (URCA), Crato, CE, Brasil. *nadghia.fl@gmail.com
}

\begin{abstract}
Baccharis cinerea belongs to the Asteraceae family, in Brazil is found in the Northeast and Southeast, occurring in the Caatinga and Mata Atlântica biomes, on the edges of the seasonal forests, board and altitude forests in both regenerating primary and secondary areas. Has proven antimicrobial and antiviral activity and is widely used in folk medicine for its various therapeutic effects and is used as an antiseptic for skin and wound infections, inflammation, diarrhea as well as being used as a purgative. The plants used in the traditional medicine are more and more explored scientifically because they are possible resources of substances with antimicrobial activity in front damage man's health microorganism. In this context the objective of the study was to investigate the antimicrobial activity, modulator activity of antibiotic and in vitro phytochemical prospection of leaf ethanol extracts. Tests were performed on the bacterial strains of Staphylococcus aureus (ATCC 25923), Pseudomonas aeruginosa (ATCC 15442) and Escherichia coli (ATCC 10536). The antibacterial activity was analyzed by means determining the Minimum Inhibitory Concentration (MIC). For the evaluation of the modulating activity, the microdilution method of the diluted extract samples with the antibiotic's amikacin, clindamycin and gentamicin was used. The MIC results were $\geq 1024 \mu \mathrm{gL}^{-1}$ by the bacterial strains. There was a relevance of concentrations in modulation with the antimicrobials tested such as amikacin and gentamicin, there were no discrepancy of clindamycin results in association with the extract. The chemical constituents found were leucoanthocyanidins, flabobenic tannins, flavanones, flavones, flavonoids, xanthones, chalcones, aurones. It is important to note that is necessary to do other studies to evaluate the potential of this species because it has important chemical compounds in reducing antimicrobial resistance.
\end{abstract}

KEYWORDS: Antibacterial activity. Modulation. Medicinal plants. Phytochemical.

\section{INTRODUCTION}

The use of medicinal plants with intention of upkeep and health recovery is related to the emergence of the human beings. (VARELA; AZEVEDO, 2014)

The plants used in the traditional medicine are more and more explored scientifically because they are possible resources of substances with antimicrobial activity in front damage man's health microorganism (BARBOSA et al., 2017).

Because Brazil has ample ethnobotanical knowledge and ample natural biodiversity it has received incentives from World Health Organization for practices in Science research about medicinal plants with therapeutic purpose (SANTANA et al., 2016).

The Baccharis genus has species distributed widely in Brazil, Argentina, Colombia, Chile and
Mexico. They were described about 120 species in Brazil with greater incidence in the southeast of the country. The species of the genus Baccharis are, in general, shrubs with 0,4 to $4,0 \mathrm{~m}$ like carqueja and vassourinha or vassoura (VERDI; BRIGHENTE; PIZZOLATTI, 2005).

Baccharis cinerea in Brazil is found in the Northeast (AL, BA, CE, PB, PE, RN) and Southeast (ES, MG, RJ, SP), occurring in the Caatinga and Mata Atlântica biomes, on the edges of the seasonal forests, board and altitude forests in both regenerating primary and secondary areas (HEIDEN; BAUMGRATZ; ESTEVES, 2012).

Baccharis trinervis (Lam) Pers., Is considered synonymous with $B$. cinerea. Abad et al. (1999) described the antiviral activity of $B$. cinerea extract, inhibiting $100 \%$ replication of herpes simplex virus type I (HVS-1). 
According to Morton (1981) and Torres (1995) the species is also cited for the treatment of snake bites, stomach pain, as an antiseptic in skin and wound infections, muscle cramps, edema, lactogen, kidney pain, inflammation, diarrhea, rheumatism, body aches, liver disease, fighting typhoid fever, hemorrhoids, as well as sexual impotence and female sterility, as well as allowing gallstones to evacuate and is used as a purgative.

Plants produce chemical substances that can exhibit various biological activities, thus still constitute a relevant therapeutic resource for a significant portion of the world's population who do not have access to industrialized medicines (TÔRRES et al., 2005). Plant properties are used both in the well-known "home medicine" as well as raw material for the preparation of herbal medicines (CORDEIRO et al., 2006; ZAGO et al., 2009).

Phytochemical studies of genus Baccharis show the emergence of flavonoids, diterpenes and tritepnes, it is found in greater proportions the flavones, flavonols and diterpenes, labdans and clerodans (VERDI; BRIGHENTE; PIZZOLATTI, 2005).

Secondary metabolites have efficient bioactive properties to control the growth of many microorganisms, such as bacterial yeast and filamentous fungi, proving that plants have a potential effect on combating these pathogenic organisms (BARBOSA et al., 2017).

The sensitivity of bacteria to antibiotics is high at first exposure, but the tendency is to decrease with subsequent exposures. Resistance is guaranteed by genetic factors, such as mutations, being transmitted by reproduction progenies and is related to indiscriminate, empirical and routine use of antibiotics (GRILLO, 2013). In addition, the ability to display rapidly causes a large number of resistant bacteria to occur in a short time (TORTORA; FUNKE; CASE, 2012).

Such plants contribute as a source of compounds of wide biological activity and their use, especially in the treatment of infectious diseases, represents a great reinforcement for the discovery of new therapeutic agents that can be used in the treatment of diseases caused by multiresistant microorganisms (PORFÍRIO et al., 2009).

Ramos Campos et al. (2016) conducted research providing an overview of chemical and pharmacological studies of essential oil, extracts, fractions and pure compounds of Baccharis species. The research concludes that most of these substances or extracts have some biological characteristics, especially antioxidant activity, which may be impaired by their anti-inflammatory and gastroprotective activities, corroborating the popular uses used for the genus Baccharis. In addition, important activities such as antimicrobial and antiprotozoal show that Baccharis species can be a promising source of active biological compounds for these diseases.

So, this research had as goal to purpose of highlighting from the Baccharis cinerea's extract in isolation or in modulation process the contribution to the inhibition of growth of bacterial strains of Staphylococcus aureus, Pseudomonas aeruginosa e Escherichia coli.

\section{MATERIALS AND METHODS}

\section{Vegetable Material}

It was determined the species during a literature review. The species was collected in the region of Cariri Cearence in district of Crato-CE, Arajara town. The exsiccates are found in the Caririense Dárdano de Andrade-Lima Herbarium HCDAL, identified by Ana Cleide Alcântara Morais Mendonça and deposited under registration 13.961.

The leaves were selected and crushed to increase the contact surface and then they were weighed using an analytical balance obtaining a weight of $485 \mathrm{~g}$. Later they were immersed in approximately $2,900 \mathrm{~mL}$ of ethanol for prolonged cold extraction for 72 hours. After this time the extract was filtered with the aid of gases and a glass funnel and subjected to the distillation of the solvent on a rotary evaporator for about three days.

It was taken to the water bath at a temperature of $50^{\circ} \mathrm{C}$ inside a glass container weighing around $152.79 \mathrm{~g}$ remaining for 10 days so that all ethanol evaporated and only the crude extract remained.

Then $0.01 \mathrm{~g}$ of the extract was weighed into an analytical balance in an eppendorf of $2 \mathrm{~mL}$. Adding $1 \mathrm{~mL}$ of Dimethylsulfoxide or dimethyl sulfoxide (DMDS) and it was taken to solution to VORTEX for complete homogenization. The mixture was transferred to a falcon tube and $8.8 \mathrm{~mL}$ of distilled water was added.

\section{Microorganisms}

The bacteria used: Staphylococcus aureus (ATCC 25923), Pseudomonas aeruginosa (ATCC 15442) and Escherichia coli (ATCC 10536).

The following culture medium was used: Brain Heart Infusion - BHI (Sigma $\left.{ }^{\circledR}\right)$ at the concentration indicated by the maker and sterilized in steam autoclave.

Bacteria were replicated in triplicate. Test tubes were then used with a solution containing 
Assessment and antimicrobial...

$100,000 \mu \mathrm{L}$ BHI and $100 \mu \mathrm{L}$ of inoculum added. Being organized as follows: 3 tubes of Pseudomonas aeruginosa, 3 tubes of Staphylococcus aureus and 3 tubes of Escherichia coli.

\section{Phytochemical Prospecting}

Phytochemical tests to detect the presence of secondary metabolites Leucoantocyanidins, flabobenic tannins, flavanones, flavones, flavonoids, xanthones, chalcones, aurones. They were done following the method described by Matos (1997) and reviewed by (MATOS, 2009). These tests are based on the visual observation of the color change or precipitate formation after the addition of specific reagents.

Two $300 \mathrm{~g}$ portions of extract were weighed. In one portion ethanol with $30 \%$ water was added and in the other portion ethyl ether was added. They were separated from $3 \mathrm{ml}$ in enumerated flasks. Stir frequently for material extraction, soon after the mixture was heated in a water bath and filtered.

Seven 3-4 mL portions were separated into enumerated test tubes and two $10 \mathrm{~mL}$ portions into labeled beakers, one of which was tared. The beers were left in a water bath until dry. The remainder of the extract was concentrated in a water bath to obtain half volume. The $\mathrm{pH}$ was adjusted to 4 and filtered.

The test for phenols and tannins was used vial 1 by adding 3 drops of $\mathrm{FeCl} 3$ alcohol solution. It was shaken well and observing any color variation or formation of abundant dark precipitate. Then compared to the blank test, that is, using only water and ferric chloride.

For anthocyanins, anthocyanidins and flavonoids the tubes number 2,3 and 4 respectively were used. One was acidified at $\mathrm{pH} 3$ with $\mathrm{HCl}$, the tube 2 alkalized with $\mathrm{NaOH}$ at $\mathrm{pH} 8.5$ and the third at $\mathrm{pH} 11$. Then the color change was observed.

The tubes numbered 5 and 6 were used for the determination of leucoanthocyanidins, catechins and flavonones. Tube 5 was acidulated with the addition of $\mathrm{HCl}$ to $\mathrm{pH} 1-3$ and vial 6 alkalized with $\mathrm{NaOH}$ to $\mathrm{pH}$ 11. The tubes were heated with an alcohol lamp for 2-3 minutes. The color change was observed compared to the tubes used in the previous test.

In the test for flavonols, flavanones, flavononols and xanthones, tube 7 was used. An amount $0.07 \mathrm{~g}$ of magnesium and $0.5 \mathrm{~mL}$ of concentrated $\mathrm{HCl}$ were added to the tube. At the end of the reaction, the color change of the reaction mixture of the tubes in tubes 5 and 7 was compared.
SANTOS, C. T. et al.

For the alkaloid test, the methodology of Bilbao (1997) was used. Solutions of the crude extract of $300 \mathrm{mg}$ diluted in $30 \mathrm{~mL}$ of $5 \%$ acetic acid were initially prepared and heated and then transferred to a separatory funnel. Then with $10 \%$ ammonium Hydroxide in a $10 \mathrm{~mL}$ sample the $\mathrm{pH}$ variation was watched using indicator paper. We added $15 \mathrm{ml}$ of chloroform in the solutions where they were homogenized and allowed to stand, in case of occurrence of alkaloids, the chloroform phase was carried out with Draggendorf reagent and drops of $1 \% \mathrm{HCl}$.

\section{Minimum Inhibitory Concentration (MIC)}

Minimal Inhibitory Concentration (MIC) is defined as the lowest concentration is can inhibit bacterial growth in the cavities of the microdilution plate as detected macroscopically (NCCLS, 2003).

MIC was performed by broth microdilution method. The inoculum deposited in saline solution to form a suspension of $10^{5} \mathrm{CFU} / \mathrm{mL}$; the extracts concentrations ranged from 1024 to $8 \mu \mathrm{g} \mathrm{mL}^{-1}$.

Then, $100 \mu \mathrm{L}$ of this solution was distributed into each cavity of the microdilution plate, and after that, $100 \mu \mathrm{L}$ of the extract was added in the first cavity and passed to the others through successive dilutions in the ratio of $1: 1$ to the penultimate cavity. The last cavity was reserved for the growth of microorganisms without interference from the evaluated substances. The plate will be placed in the oven at a temperature of approximately $37^{\circ} \mathrm{C}$ for a period of 24 hours, the plates containing bacteria developed with specific dye, resazurin, a calorimetric oxide-reduction indicator. To perform the test reading it was necessary to add $20 \mu \mathrm{L}$ of the solution in each cavity of the plates and to incubate them for $1 \mathrm{~h}$ at room temperature (SALVAT et al., 2001).

The disclosure of MIC considered as inhibition of growth for cavities that remained with blue staining and non-inhibition were those that obtained red staining.

\section{Modulation of antibiotic activity by microdilution}

The extract was tested in subinhibitory concentration (MIC/8). $1163 \mu \mathrm{L}$ of a solution containing BHI, $150 \mu \mathrm{L}$ of inoculum and $187 \mu \mathrm{L}$ of the extract were distributed in each cavity identified as MIC. In the cavities identified as CONTROL, $1350 \mu \mathrm{L}$ of $\mathrm{BHI}$ and $150 \mu \mathrm{L}$ of inoculum were distributed. All distribution done in the alphabetical order of the plate. Subsequently, $100 \mu \mathrm{L}$ of the antibiotic, in concentration of $5000 \mu \mathrm{mL}^{-1}$ were mixed into the first cavity, acting the microdiluted 
in serie at a ratio of $1: 1$ to the penultimate cavity. Antimicrobial concentrations varied gradually from 5000 to $2,44 \mu \mathrm{g} \mathrm{mL}{ }^{-1}$.

\section{RESULTS AND DISCUSSION}

Secondary metabolites found in Baccharis cinerea extract were revealed by qualitative phytochemical analysis. In phytochemical prospecting a variety of secondary metabolites was identified: Leucoantocyanidins, flabobenic tannins, flavanones, flavones, flavonoids, xanthones, chalcones, aurones.

The absence of other components may be related to seasonal variations, collection time, genetic differences, storage conditions, among other factors (BARBOSA et al., 2017).

Described as phenolic polymers, tannins are plant secondary metabolites that precipitate proteins acting as a mechanism against microbial infections. Leucoantocyanides and flavones have antiinflammatory, antioxidant, antifungal activities besides antibacterial action (BATTESTIN; MATSUDA; MACEDO, 2008; ARAÚJO, 2008).

The Minimum Inhibitory Concentration (MIC) test with the bacteria (E. coli, S. aureus and $P$. aeruginosa) resulted in a concentration of $\geq 1024$ $\mu \mathrm{g} \mathrm{mL}{ }^{-1}$ in all strains.

Inhibition of growth of Pseudomonas aeruginosa strains (Figure 1) with the antimicrobial
Amikacin was more significant when it was associated with the Baccharis cinerea extract compared to its isolated use, where the inhibitory concentration of Amikacin was $2.500 \mu \mathrm{g} \mathrm{mL}^{-1}$ and concomitant use with the extract was $1.250 \mu \mathrm{g} \mathrm{mL}^{-1}$. In case of clindamycin there was no difference in concentrations for inhibition of growth of the Pseudomonas aeruginosa strain, where the concentrations of modulation and control were $4.882 \mu \mathrm{g} \mathrm{mL}^{-1}$. Gentamicin showed greater relevance in the modulation where its inhibition concentration was $496.063 \mu \mathrm{g} \mathrm{mL} \mathrm{m}^{-1}$ and in the control was $992,126 \mu \mathrm{g} \mathrm{mL}{ }^{-1}$.

It is possible the effect of growth inhibition is related to the presence of secondary metabolites such as it was shown in the work of (PROENÇA et al., 2014), xanthones, oxygen-containing heterocyclic compounds with base structure a dibenzo-y pyrone, arouse great interest due to biological activities such as antimicrobial.

Another work presenting xanthones, catechins, flavones, flavonols, flavanones and thannins as secondary metabolites in common with the research performed showed great antimicrobial activity. The hydroalcoholic extracts of aroeira, barbatimão and barberry leaves belonging to the Asteraceae present antibacterial activity (PINHO et al., 2012).

\section{Pseudomonas aeruginosa}

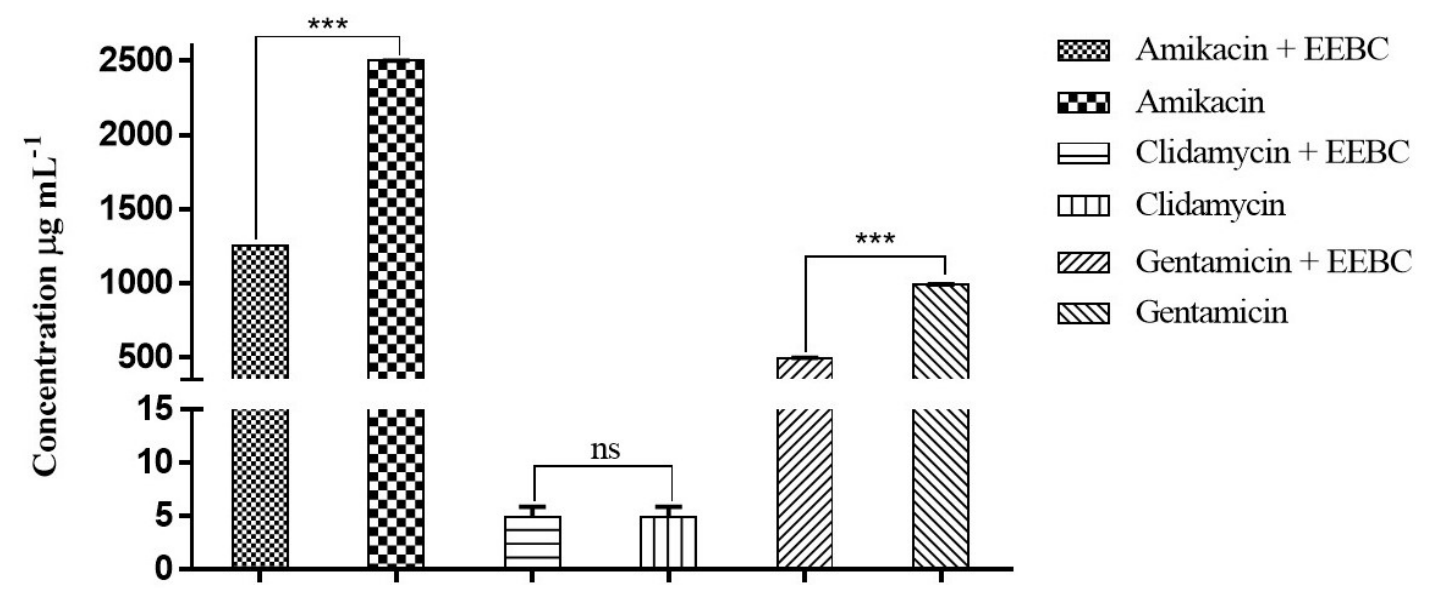

Figure 1. Antibiotic modulating activity of the ethanolic extract of Baccharis cinerea leaves - EEBC against Pseudomonas aeruginosa. *** Statistically significant value with $\mathrm{p}<0.0001$. ns - not statistically significant.

The strains of Escherichia coli (Figure 2) obtained a concentration of inhibition of growth with greater importance in the use of the association of Amikacin with the extract of Baccharis cinerea where its concentration was of $196.842 \mu \mathrm{g} \mathrm{mL}^{-1}$, and of $502,591 \mu \mathrm{g} \mathrm{mL}^{-1}$ for the control. However, there was no distinction between modulation and control of Clindamycin, concentrations were $787.451 \mu \mathrm{g}$ 
$\mathrm{mL}^{-1}$. On The other hand the use of Gentamicin in association to Baccharis cinerea extract showed a better inhibition of Escherichia coli strains when it was compared to the antimicrobial use alone, where their respective concentrations were $31.004 \mu \mathrm{g} \mathrm{mL}^{-1}$ and $49.215 \mu \mathrm{g} \mathrm{mL}^{-1}$.

\section{Escherichia coli}

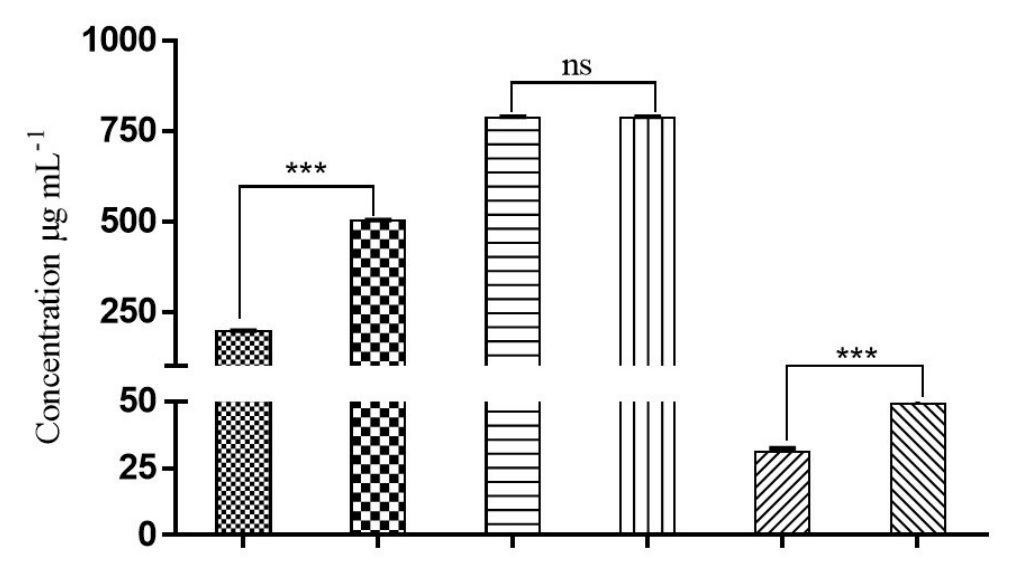

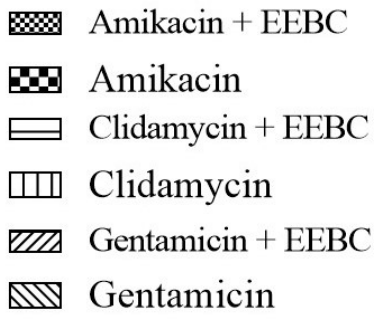

Gentamicin

Figure 2. Antibiotic modulating activity of the ethanolic extract of Baccharis cinerea leaves - EEBC against Escherichia coli. ${ }^{* *}$ Statistically significant value with $\mathrm{p}<0.0001$. ns - not statistically significant.

Inhibition of the growth of Staphylococcus aureus strains in association to the ethanolic extract of Baccharis cinerea leaves and with the antimicrobial Amikacin showed important results where in the modulation a concentration of 124.016 $\mu \mathrm{g} \mathrm{mL} \mathrm{L}^{-1}$ and a control of $312,500 \mu \mathrm{g} \mathrm{mL} \mathrm{m}^{-1}$ was necessary (Figure 3 ). There were no divergence in concentrations at the modulation and isolated use of Clindamycin where the concentrations were of $19.531 \mu \mathrm{g} \mathrm{mL}^{-1}$. The association of the extract with Gentamicin where its inhibitory concentration was $78.125 \mu \mathrm{g} \mathrm{mL}^{-1}$ and the control $156.250 \mu \mathrm{g} \mathrm{mL}^{-1}$ was effective.

\section{Staphylococcus aureus}

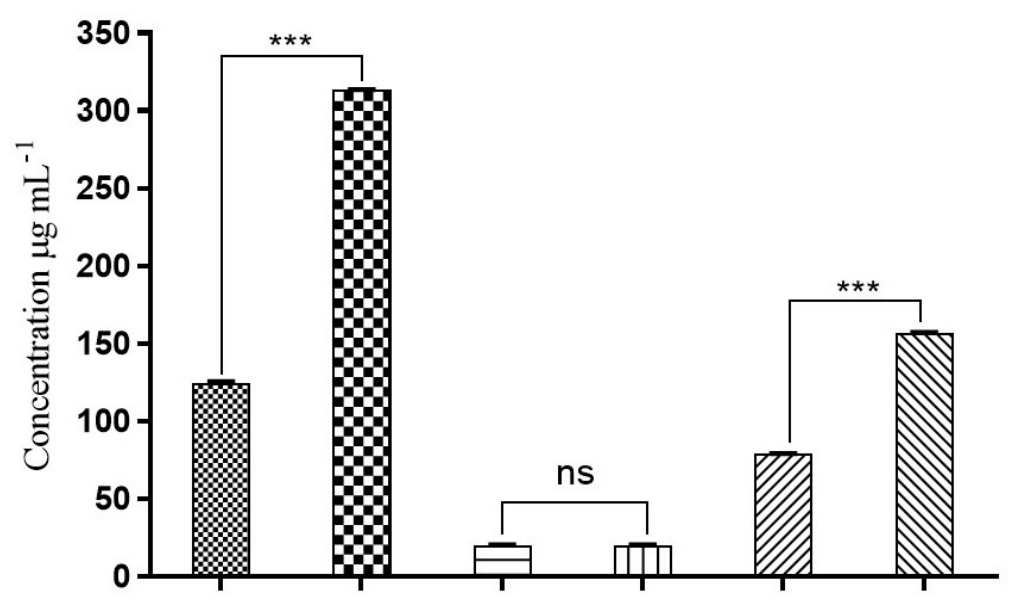

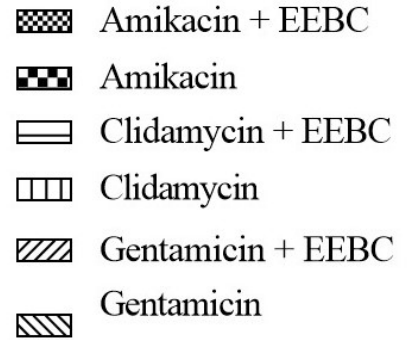

Amikacin + EEBC

Gentamicin

Figure 3. Antibiotic modulating activity of the ethanolic extract of Baccharis cinerea leaves - EEBC agaist Staphylococcus aureus. ${ }^{* * *}$ Statistically significant value with $\mathrm{p}<0.0001$. ns - not statistically significant.

Other works with Baccharis species showed antimicrobial activity. In Baccharis dracunculifolia D.C. and Baccharis uncinella D.C. (FERRONATTO et al., 2007) verified antimicrobial activity in relation to $S$. aureus, E. coli and $P$. aeruginosa.

Evaluation of antimicrobial activity and ethanolic extract of $B$. trinervis showed inhibitory 
ability on growth of Streptococcus pneumoniae and Staphylococcus aureus at a minimum inhibitory dose (MIC) of $250 \mathrm{mg} \mathrm{mL}^{-1}$; Candida albicans 125 $\mathrm{mg} \mathrm{mL}^{-1}$ and Cryptococcus neoformans $250 \mathrm{mg} \mathrm{mL}^{-}$ 1 .

The family Asteraceae already known for its therapeutic, aromatic and cosmetic properties. There is already in the literature its medicinal use as antimicrobial, anthelmintic, anti-inflammatory, astringent, diuretic, analgesic, cholesteric and antispasmodic. In the study of Fabri et al. (2011) the antimicrobial activity was verified in a study of the extract of Baccharis dracunculifolia for $P$. aeruginosa, B. cereus and C. neoformans with (MIC

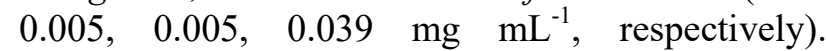
Baccharis trimera also demonstrated significant activity for C. neoformans (MIC $0.039 \mathrm{mg} \mathrm{mL}^{-1}$ ).

The results obtained in the modulation may be relation to the interaction of the drug with the secondary metabolites present in the extract of leaves of Baccharis cinerea.

From the preliminary phytochemical prospection, secondary metabolites like flobabenic tannin and flavanones (condensed) with antimicrobial and antioxidant action were found containing some mechanisms of action are able to inhibit bacterial growth and potentiating antimicrobials, reducing the concentration of these drugs by the modulating action (SIMÕES et al, 2010).

The antimicrobial activity of the genus Baccharis is confirmed in another study, (ABREU; ONOFRE, 2010). The tests were carried out using the hydroalcoholic extract of Baccharis dracunculifolia D.C, where it showed inhibition of growth of two strains tested on $S$. aureaus and $E$. coli.

\section{CONCLUSION}

According to the results obtained and through use the methodology we can conclude that the ethanolic extract of Baccharis cinerea DC. evaluated in relation to the pathogenic bacteria Escherichia coli, Pseudomonas aeruginosa and Staphylococcus aureus were efficient against modulation with the antimicrobials Amikacin and Clindamycin by inhibiting the microorganisms tested.

Later studies are needed to test cell cytotoxicity and fractionation of extracts for the identification of antimicrobial compounds.

According to the results obtained Baccharis cinerea of Cariri Cearense can be considered a promising species for the development of new antimicrobial drugs.

RESUMO: Baccharis cinerea pertence à família Asteraceae, no Brasil é encontrada nas regiões Nordeste e Sudeste, ocorrendo nos biomas Caatinga e Mata Atlântica, nas bordas das florestas estacionais, tabuleiro e de altitude em áreas primárias e secundárias em regeneração. Tem atividade antimicrobiana e antiviral comprovada e é amplamente utilizado na medicina popular por seus diversos efeitos terapêuticos, sendo utilizado como antisséptico para infecções de pele e feridas, inflamação, diarreia e também como purgante. As plantas utilizadas na medicina tradicional são cada vez mais exploradas cientificamente, pois são possíveis recursos de substâncias com atividade antimicrobiana que prejudicam a saúde do homem. Neste contexto o objetivo do estudo foi investigar a atividade antimicrobiana, atividade moduladora de antibióticos e prospecção fitoquímica in vitro de extratos etanólicos de folhas. Os testes foram realizados nas cepas bacterianas de Staphylococcus aureus (ATCC 25923), Pseudomonas aeruginosa (ATCC 15442) e Escherichia coli (ATCC 10536). A atividade antibacteriana foi analisada por meio da determinação da Concentração Inibitória Mínima (CIM). Para avaliação da atividade moduladora, foi utilizado o método de microdiluição das amostras do extrato diluído com os antibióticos amicacina, clindamicina e gentamicina. Os resultados da MIC foram $\geq 1024 \mu \mathrm{g} \mathrm{mL}^{-1}$ pelas cepas bacterianas. Houve relevância das concentrações na modulação com os antimicrobianos testados como amicacina e gentamicina, não havendo discrepância nos resultados da clindamicina em associação com o extrato. Os constituintes químicos encontrados foram leucoantocianidinas, taninos flabobênicos, flavanonas, flavonas, flavonóides, xantonas, chalconas, auronas. É importante ressaltar que é necessária a realização de outros estudos para avaliar o potencial desta espécie, pois possui compostos químicos importantes na redução da resistência aos antimicrobianos.

PALAVRAS-CHAVE: Atividade antibacteriana. Fitoquímico. Modulação. Plantas medicinais. 


\section{REFERENCES}

ABAD, M. J. et al. Antiviral activity of some South American medicinal plants. Phytotherapy Research: An International Journal Devoted to Pharmacological and Toxicological Evaluation of Natural Product Derivatives, v. 13, n. 2, p. 142-146, 1999. https://doi.org/10.1002/(SICI)1099-1573(199903)13:2<142::AIDPTR392>3.0.CO;2-7

DE ABREU, P. A. P.; ONOFRE, S. B. Atividade antimicrobiana dos extratos de Baccharis dracunculifolia DC (Asteraceae). SaBios-Revista de Saúde e Biologia, v. 5, n. 2, 2010.

ARAÚJO, . Química de alimentos: teoria e prática. In: Química de alimentos: teoria e prática. 2004. p. 478478.

BARBOSA, H. M. et al. Abordagem fitoquímica de metabólitos secundários em Solanum acanthodes (Solanaceae) Hook. South American Journal of Basic Education, Technical and Technological, v. 4, n. 1, 2017.

BATTESTIN, V.; MATSUDA, L.; MACEDO, G. A. Fontes e aplicações de taninos e tanases em alimentos. Alimentos e Nutrição Araraquara, v. 15, n. 1, p. 63-72, 2008.

BILBAO, M. R. R. Analyze preliminary chemical phytochemistry of natural products. Universidad del Quindío. Armênia, 1997.

CORDEIRO, C. H. G. et al. Avaliação farmacognóstica e atividade antibacteriana de extratos vegetais empregados em gel dentifrício. Revista Brasilera de Plantas Medicinales, Botucatu, v. 8, n. 4, p. 173-182, 2006.

FABRI, R. L. et al. Potencial antioxidante e antimicrobiano de espécies da família Asteraceae. Revista Brasilera de Plantas Medicinales, Botucatu, v.13, n.2, p. 183-189, 2011. https://doi.org/10.1590/S151605722011000200009

FERRONATTO, R. et al. Atividade antimicrobiana de óleos essenciais produzidos por Baccharis dracunculifolia DC e Baccharis uncinella DC (Asteraceae). Revista Brasileira de farmacognosia, v. 17, n. 2 , p. 224-230, 2007. https://doi.org/10.1590/S0102-695X2007000200016

GRILLO, V. T. R. S. et al. Incidência bacteriana e perfil de resistência a antimicrobianos em pacientes pediátricos de um hospital público de Rondônia, Brasil. Revista de Ciências Farmacêuticas Básica e Aplicada, v. 34, n. 1, p. 117-123, 2013.

HEIDEN, G.; BAUMGRATZ, J. F. A.; ESTEVES, R. L. Baccharis subgen. Molina (Asteraceae) no estado do Rio de Janeiro, Brasil. Rodriguésia, v. 63, n. 3, p. 649-687, 2012. https://doi.org/10.1590/S217578602012000300013

MATOS, FJ de A. Introdução à Fitoquímica Experimental. 2º ed, Fortaleza: Edições UFC, 1997.

MATOS, FJ de A. Introdução a Fitoquímica Experimental. $3^{\circ}$ ed, Fortaleza: Edições UFC, 2009.

MORTON, J. F. et al. Atlas of medicinal plants of Middle America: Bahamas to Yucatan. Charles C. Thomas, 1981.

NCCLS. Performance Standards for Antimicrobial Disk Susceptibility Tests; Approved Standard. Pennsylvania, USA, 2003. 
PINHO, L. et al. Atividade antimicrobiana de extratos hidroalcoolicos das folhas de alecrim-pimenta, aroeira, barbatimão, erva baleeira e do farelo da casca de pequi. Ciência Rural, v. 42, n. 2, p. 326-331, 2012. https://doi.org/10.1590/S0103-84782012005000003

PORFÍRIO, Z. et al. Atividade antimicrobiana de extratos hidroalcoólicos de Lafoensia pacari A. St.-Hil., Lythraceae, frente a bactérias multirresistentes de origem hospitalar. Revista Brasileira de Farmacognosia, v. 19, n. 3, p. 785-789, 2009. https://doi.org/10.1590/S0102-695X2009000500023

PROENÇA, C. et al. Síntese de novas cromonas e xantonas com atividade captadora de espécies reativas de oxigênio. $1^{\circ}$ Edição, Porto-Portugal: Sociedade Portuguesa de Química, 2014.

SALVAT, A. et al. Screening of some plants from Northern Argentina for their antimicrobial activity. Letters in Applied Microbiology, 32: 293-297, 2001. https://doi.org/10.1046/j.1472-765X.2001.00923.x

SANTANA, P. S. et al. Efeito antibacteriano e antifúngico de extratos etanólico, hexânico e metanólico a partir de folhas de Kalanchoe pinnata (Lam.) Pers (Malva corama) contra cepas multi-resistentes a drogas. Biota Amazônia (Biote Amazonie, Biota Amazonia, Amazonian Biota), v. 6, n. 1, p. 64-69, 2016. https://doi.org/10.18561/2179-5746/biotaamazonia.v6n1p64-69

SIMÕES, C. M. O. Farmacognosia: da planta ao medicamento. 6 ed. Porto Alegre: Universidade Federal do Rio Grande do Sul, 2010.

TORTORA, G. J.; FUNKE, B. R.; CASE, C. L.; Microbiologia. Ed 10ª Porto Alegre: Artmed, 2012.

VARELA, D. S. S.; DE AZEVEDO, D. M. Opinião de médicos e enfermeiros sobre o uso da fitoterapia e plantas medicinais na atenção básica. Revista de APS, v. 17, n. 2, 2014.

VERDI, L. G.; BRIGHENTE, I. M. C.; PIZZOLATTI, M. G. Gênero Baccharis (Asteraceae): aspectos químicos, econômicos e biológicos. Química Nova, v. 28, n. 1, p. 85-94, 2005. https://doi.org/10.1590/S010040422005000100017

ZAGO, J. AA et al. Synergism between essential oils and antimicrobial drugs against Staphylooccus aureus and Escherichia coli strains from human infections. Revista Brasileira de Farmacognosia, v. 19, n. 4, p. 828-833, 2009. https://doi.org/10.1590/S0102-695X2009000600005 